\title{
Expression of ERa36 in gastric cancer samples and their matched normal tissues
}

\author{
JIANJUN WANG ${ }^{1 *}$, JIAJIA LI $^{2 *}$, RENGUI FANG $^{1}$, SHUDUO XIE $^{3}$, LINBO WANG $^{3}$ and CHAOYANG XU ${ }^{2,3}$ \\ ${ }^{1}$ Department of Surgical Oncology, The Chunan County First Hospital, Zhejiang 312030; ${ }^{2}$ Department of Breast \\ and Thyroid Surgery, Shaoxing People's Hospital, The First Affiliated Hospital of Shaoxing University, \\ Zhejiang 312000; ${ }^{3}$ Department of Surgical Oncology, Sir Run Run Shaw Hospital, \\ College of Medicine, Zhejiang University, Zhejiang 310000, P.R. China
}

Received June 21, 2011; Accepted September 29, 2011

DOI: $10.3892 / 01.2011 .437$

\begin{abstract}
Estrogen receptor $\alpha 36(\mathrm{ER} \alpha 36)$ is believed to mediate membrane-initiated effects of estrogen signaling, and promote cell growth and resistance to tamoxifen treatment. However, few studies are available regarding ER $\alpha 36$ expression in gastric cancer. In the present study, we evaluated the expression of ER $\alpha 36$, as well as estrogen receptor $\alpha 66$ (ER $\alpha 66$ ), in gastric cancer and its correlation with clinicopathological parameters. Real-time polymerase chain reaction (PCR) was applied to detect the expression of ER $\alpha 66$ and ER $\alpha 36$ mRNA in 45 pairs of samples of gastric cancer tissues and matched normal tissues. The $\Delta \Delta \mathrm{CT}$ method was used to evaluate the relative quantity of target mRNA expression. Among the 45 pairs of samples of gastric cancer tissues and matched normal tissues adjacent to the tumor, the ER $\alpha 36$ mRNA levels in normal tissues were significantly higher than those observed in gastric cancer tissues $(\mathrm{p}=0.040)$. Additionally, the expression of ER $\alpha 66$ mRNA levels between gastric cancer tissues and matched normal tissues had no statistically significant difference. We confirmed that ER $\alpha 36$ mRNA was expressed in the four gastric cancer cell lines, and ERa66 mRNA was expressed in two of the four gastric cancer cell lines. According to the tissue and cell findings, it was suggested that the expression level of ER $\alpha 36$ is greater than that of ER 666 in gastric cancer. In conclusion, the expression of ER $\alpha 66$ and ER $\alpha 36$ in gastric cancer tissues and cells was confirmed in this study. A decreased expression of ER $\alpha 36$ mRNA in gastric cancer tissues may be one of the factors affecting tumorigenesis in gastric cancer patients.
\end{abstract}

Correspondence to: Dr Chaoyang Xu, Department of Breast and Thyroid Surgery, Shaoxing People's Hospital, The First Affiliated Hospital of Shaoxing University, Zhejiang 312000, P.R. China

E-mail: xuchaoyang2001@126.com

*Contributed equally

Key words: gastric cancer, estrogen receptor $\alpha 36$, estrogen receptor $\alpha 66$, variation, polymerase chain reaction

\section{Introduction}

Findings of recent studies have shown that there is a possible correlation of estrogen with the biological activity of gastric cancer cells (1), and that the expression of estrogen receptor a66 (ER $\alpha 66$ ) may correlate with poorer prognosis among patients with gastric cancer (2).

ER $\alpha 36$, a novel variant of the full-length $66 \mathrm{kDa}$ ER $\alpha 66$, has one of the most crucial roles in cell growth and differentiation in various types of cancer (3). This variant differs from ER $\alpha 66$ by lacking the transcriptional activation domains (AF-1 and AF-2), but retains the partial dimerization and ligand-binding domains and DNA-binding domain.

ER $\alpha 36$ enhances oncogenesis, and promotes cell growth and survival during endocrine therapy in breast cancer (4). The expression of ER $\alpha 36$ was subsequently detected in breast (5), colorectal (6) and endometrial cancer (7). Furthermore, unlike ER $\alpha 66$, which is often detected in the cell nucleus, ER $\alpha 36$ is located in the cytoplasm and plasma membrane. As a result, ER $\alpha 36$ mediates the membrane-initiated effects of estrogen signaling cascades and stimulates cell growth $(3,8)$. These features make ER $\alpha 36$ an attractive target for antibody-based therapy.

The expression of ERa66 has been detected in gastric cancer cell lines as well as in normal and cancer tissues. However, the physiological role of ERa66's possible involvement in the etiology of gastric cancer remains to be clarified. Recently, it was reported that the effect of tamoxifen treatment in ERa66-positive breast tumors could be prevented by ERa36. A similar event may occur in other types of cancer, including gastric cancer. Therefore, understanding the existence and expression status of ER $\alpha 36$ may have significant implications in the prognosis and treatment of gastric cancer.

Although ERa36 has been extensively studied in other types of cancer, no investigation has been conducted in gastric cancer. We hypothesize that ER $\alpha 66$ and its splicing variant ER $\alpha 36$ may play a role in the oncogenesis of gastric cancer. The present study was undertaken to examine the expression of ER $\alpha 36$ and ER $\alpha 66$ in gastric cancer tissues by using a validated specific and sensitive real-time quantitative PCR assay. In this study, we examined tissue from 45 cases of gastric cancer to observe the potential difference of ERa66 and 
ER $\alpha 36$ expression in gastric cancer tissues and their matched normal tissues, and to assess the correlation between ERa66 and ER $\alpha 36$ expression and clinicopathological characteristics in gastric cancer patients.

\section{Materials and methods}

Case selection. Specimens were obtained from 45 patients who underwent curative resection of gastric cancer at the Department of Surgical Oncology of the Sir Run Run Shaw Hospital, Zhejiang University College of Medicine, China, between July 2007 and November 2009. Informed consent was obtained from all patients, and the study was conducted according to the guidelines of the Hospital Ethics Committee. The patients comprised 26 males and 19 females, aged 35-81 years (mean 60.0). The correlation between the expression of ER $\alpha 36$ and ER $\alpha 66$ and clinicopathological parameters including age, gender, differentiation state, location and pTNM pathological classification according to the International Union against Cancer (UICC) (9) were evaluated. The clinicopathological characteristics of the 45 cases are shown in Table I.

Cell culture. Four gastric cancer cell lines, AGS, MKN-45, NCL-N87 and SGC-7901, were maintained in Roswell Park Memorial Institute (RPMI)-1640 medium supplemented with $10 \%$ heat-inactivated fetal calf serum, $100 \mathrm{U} / \mathrm{ml}$ penicillin $\mathrm{G}$ and $100 \mathrm{mg} / \mathrm{ml}$ streptomycin.

RNA extraction and cDNA synthesis. Total RNA was extracted from freshly frozen gastric tissues using the TRIzol reagent (Invitrogen Life Technologies, Carlsbad, CA, USA). Total RNA was reverse-transcribed into single-strand complementary DNA (cDNA) using Moloney-murine leukemia (M-MLV) reverse transcriptase (Promega, Madison, WI, USA). Briefly, the RNA was denatured by heating for $5 \mathrm{~min}$ at $70^{\circ} \mathrm{C}$, cooled on ice, and then used for reverse transcription $(2 \mu \mathrm{g}$ of total RNA, $25 \mathrm{U}$ of RNAse inhibitor, $0.5 \mathrm{mM}$ each of dNTPs, $1.5 \mu \mathrm{M}$ reverse primer and $200 \mathrm{U}$ of M-MLV reverse transcriptase in a total volume of $25 \mu \mathrm{l}$ ). For reverse transcription, tubes were incubated at $42^{\circ} \mathrm{C}$ for $60 \mathrm{~min}$, followed by rapid cooling.

Real-time quantitative PCR. Real-time RT-PCR analyses were performed with the ABI Prism 7500 sequence detection system (Applied Biosystems, Foster City, CA, USA). Reaction mixture $(25 \mu \mathrm{l})$ containing $2 \mu \mathrm{l}$ of cDNA template, $1 \mu \mathrm{l}$ each of sense and anti-sense primers and $1 \mathrm{X}$ SYBR-Green Universal PCR Mix was amplified as follows: denaturation at $95^{\circ} \mathrm{C}$ for $10 \mathrm{~min}$ and 40 cycles at $95^{\circ} \mathrm{C}$ for $30 \mathrm{sec}, 60^{\circ} \mathrm{C}$ for $30 \mathrm{sec}$ and $72^{\circ} \mathrm{C}$ for $40 \mathrm{sec}$. Real-time quantitative PCR was performed in triplicate for each sample and a mean value of glyceraldehyde 3-phosphate dehydrogenase (GAPDH) was used to calculate mRNA levels. Quantitative analysis was performed using the comparative CT method $(10,11)$. The ER $\alpha 66$ and ER $\alpha 36$ mRNA copy numbers in normal and tumor tissues were normalized to mRNA copy numbers of the housekeeping gene, GAPDH to give a value of $\triangle \mathrm{CT}$. This final value was to determine changes in the expression of ER $\alpha 66$ and ER $\alpha 36$ in each sample. The primer sequences for ER $\alpha 66$ were: forward 5'-A AGA A AGA ACA ACATCAGCAGTA A AGCT-3'; and reverse 5'-GGGCTATGGCTTGGTTAAACAT-3'. The
Table I. Clinicopathological characteristics of 45 patients with gastric cancer.

Clinicopathological characteristics

Case (n)

Age

$\leq 60$

25

$>60$

20

Gender

Male

26

Female

19

Histological type

Differentiated

Undifferentiated

Location

Upper or whole

Middle or lower

30

Tumor size $(\mathrm{cm})$

$\leq 5.5$

24

$>5.5$

21

Outside of serosal

Yes

No

Node stage

N0-1

$\mathrm{N} 2-3$

primer sequences for ER $\alpha 36$ were: forward, 5'-CCAAGAATG TTCAACCACAACCT-3'; and reverse 5'-GCACGGTTCATT AACATCTTTCTG-3'. The primers for GAPDH were obtained as previously described (12). Fluorescent data were converted i) into RQ measurements, which represent relative expression, ii )automatically by the SDS system software and iii) exported to Microsoft Excel. Thermal dissociation plots were examined for biphasic melting curves, indicative of whether primer dimers or other non-specific products may be contributing to the amplification signal.

Statistical analysis. Statistical analysis was conducted using the statistical program SPSS 15.0 for Windows (SPSS, Chicago, IL, USA). Pre-treatment characteristics were analyzed using the two-tailed $\chi^{2}$ test. The two-tailed t-test was used to evaluate the correlation between ER $\alpha 36$ expression and the clinicopathological parameters.

\section{Results}

Real-time quantitative PCR of the expression of ER 36 and ERa66 in gastric cancer cells. To evaluate mRNA expression of ER $\alpha 66$ and ER $\alpha 36$ in cancer cells, we detected four gastric cancer cell lines. As shown in Fig. 1, ER $\alpha 66$ mRNA was detected in two cell lines, AGS and NCI-N87. By contrast, ER $\alpha 36$ mRNA was detected in the four cell lines. Consistent with the clinical data, the expression of ER $\alpha 36$ mRNA was more predominant than the ER $\alpha 66$ mRNA expression. 
Table II. Relative quantity of ER $\alpha 36$ mRNA and ER $\alpha 66$ mRNA in gastric cancer tissues and matched normal tissues.

\begin{tabular}{lccr}
\hline & Tumor tissue & Normal tissues & P-value \\
\hline Relative ER $\alpha 36$ expression & $1.73 \pm 5.85$ & $10.54 \pm 2.70$ & 0.040 \\
Relative ER $\alpha 66$ expression & $(7.87 \pm 15.66) \times 10^{-3}$ & $(4.30 \pm 6.98) \times 10^{-3}$ & 0.135 \\
\hline
\end{tabular}

Table III. Correlation between the expression of ER $\alpha 36$ mRNA and the number of metastasis lymph nodes, tumor size.

\begin{tabular}{lccr}
\hline & ER $\alpha 36$ expression level $\leq 0.237$ & ER $\alpha 36$ expression level $>0.237$ & P-value \\
\hline Number of metastasis lymph nodes & $11.4 \pm 11.3$ & $7.3 \pm 7.1$ & 0.150 \\
Tumor size & $6.4 \pm 2.4$ & $5.2 \pm 2.6$ & 0.100 \\
\hline
\end{tabular}

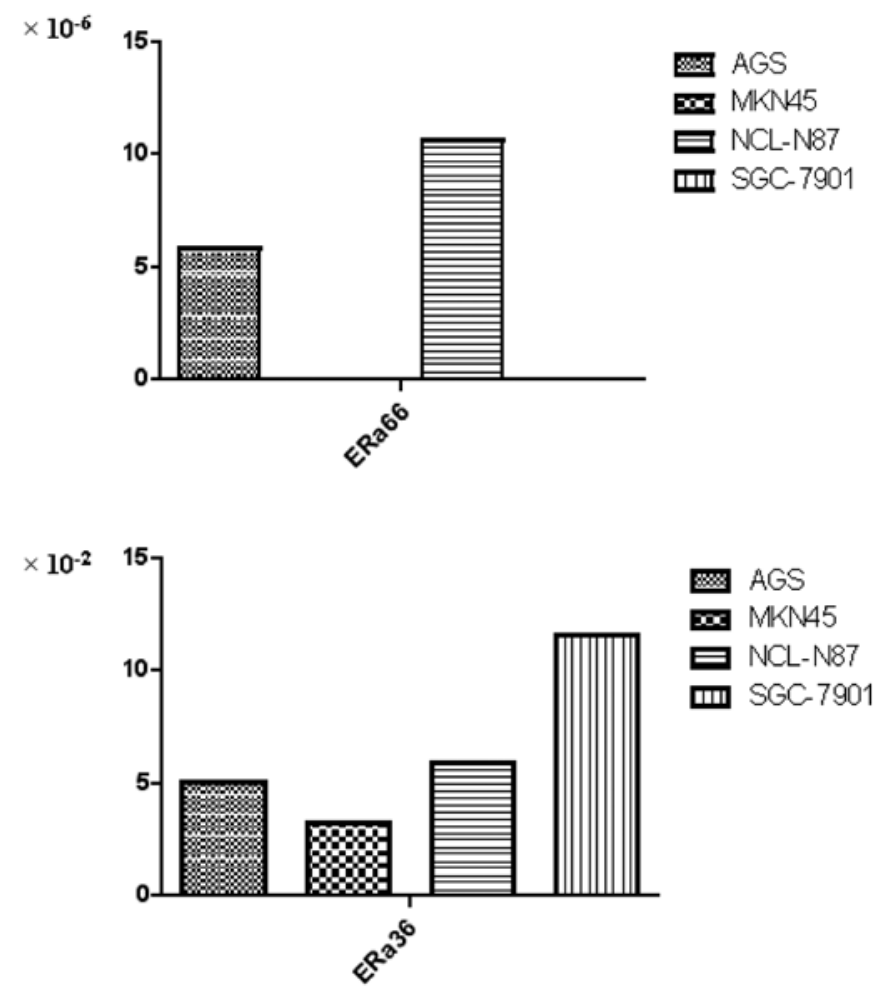

Figure 1. ER $\alpha 66$ and ER $\alpha 36$ mRNA expression level in gastric cancer cells (AGS, MKN45, NCL-N87, SGC-7901).

Expression of ERa36 and ERa66 mRNA in gastric cancer tissues by real-time PCR. Among the 45 pairs of samples of gastric cancer tissues and matched normal tissues adjacent to the tumor, the level of ERa66 of the former was similar to that of the latter, and no significant associations were found between ERa66 mRNA expression in gastric cancer tissues and normal tissues $(\mathrm{p}=0.135)$.

As shown in Table II, of the 45 samples of gastric cancer tissues and matched normal tissues adjacent to the tumor, expression of ER $\alpha 36$ was detected in the total samples. In normal tissues, the ER $\alpha 36 \mathrm{mRNA}$ levels ranged from 0.029 to 157.696 with a median of 2.016. In gastric cancer tissues, the ER $\alpha 36$ mRNA levels ranged from 0.004 to 39.233 with a median of 0.237 . The ER $\alpha 36$ mRNA levels in normal tissues were significantly higher than those observed in gastric cancer tissues $(\mathrm{p}=0.040)$. Moreover, we found that the expression of ER $\alpha 36$ mRNA was higher than that of ER $\alpha 66$ mRNA in gastric cancer tissues and their matched normal tissues.

Correlation between ER 36 and clinicopathological parameters. According to the median expression level of ER $\alpha 36$, the 45 cases of gastric cancer were divided into two groups, the high ERa36 expression group (ERa36 expression level $>0.237$ ) and the low ER $\alpha 36$ expression group (ER $\alpha 36$ expression level $\leq 0.237$ ). The mean number of metastasis lymph nodes in the high ER $\alpha 36$ group was lower than that in the low ER $\alpha 36$ expression group (11.4 vs. 7.3), but the differences among them were not statistically significant $(p=0.150)$ (Table III). Moreover, tumor size varied between the high ER $\alpha 36$ expression group versus the low ER $\alpha 36$ expression group $(6.4 \mathrm{~cm}$ vs. $5.2 \mathrm{~cm})$, but the difference was also not statistically significant $(\mathrm{p}=0.099)$ (Table III).

\section{Discussion}

In the present study, we found the relative quantity of ER $\alpha 36$ mRNA and ERa66 mRNA in 45 samples of gastric cancer tissues as determined by real-time PCR. ER $\alpha 36$ mRNA was expressed more predominantly than ER $\alpha 66$ mRNA in gastric cancer and normal tissues adjacent to the tumor.

Recent studies have shown conflicting results of ER $\alpha$ expression in gastric cancer $(13,14)$. Moreover, when using the immunohistochemical method, the expression of ER $\alpha$ gastric cancer tissues showed marked variability (0-62.5\%) among a number of studies (15-17). These data suggested that a more reliable and sensitive method was required to evaluate the ER $\alpha$ expression in gastric cancer tissues, particularly those with low expression levels. In the current study, real-time quantitative PCR was used to compare the expression of ERa66 and its splice variant ER $\alpha 36$ mRNA in 45 cases of gastric cancer and their matched normal tissues, which allows the detection of ER $\alpha$ expression in stomach tissues at a low level. In our study, the expression of another ER $\alpha 66$ splice variant, ER $\alpha 46$ mRNA, was also detected; however, it was found in neither the gastric cancer cells nor the gastric cancer tissues.

Estrogen not only modulates cell proliferation in classic estrogen-sensitive tissues, but also in other tissues such as 
the lungs (18), colon (19) and stomach $(15,16)$. An epidemiological study showed that tamoxifen, an anti-estrogen agent, may increase the incidence of gastric cancer, which suggested that estrogen may be involved in the pathogenesis of gastric cancer (20). However, few studies have reported the expression of ER $\alpha 66$ and its variant forms in gastric cancer.

In the present study, we determined not only ER $\alpha 66$, but also, for the first time, its splicing variant ER $\alpha 36$ mRNA in gastric cancer samples and their matched normal tissues by real-time quantitative PCR assay. Furthermore, we correlated these findings with the clinicopathological parameters of the gastric cancer samples.

The expression levels of ER $\alpha 66$, between gastric cancer tissues and normal tissues did not exhibit a significant difference, and the expression level was extremely low. ER $\alpha 36$ had a differential expression level between normal and cancer tissues, suggesting that ER $\alpha 36$ plays a more significant role in stomach tumorigenesis, and the decrease in this variant was significantly correlated with increased tumor size. This result suggests that ER $\alpha 36$ is involved in gastric cancer proliferation.

Recently, it was reported that aromatase expression in gastric cancer cells, and cancer cells in the presence of testosterone, produced estradiol in a short incubation period, suggesting estrogen is also localized in human gastric cancer tissues (21). However, a randomized, controlled study of adjuvant tamoxifen therapy in gastric cancer found that estrogen receptor $\alpha$ expression is an independent prognostic factor. By contrast, tamoxifen had no effect on overall survival in gastric cancer patients; furthermore, treatment with tamoxifen significantly decreased the survival time of patients with estrogen receptor $\alpha$-positive tumors (22).

It is notable that breast cancer patients with ER $\alpha 66$ expression-positive tumors that also express high levels of ER 36 are less likely to benefit from tamoxifen treatment (4). In our study, ERa36 mRNA was expressed more predominantly than ERa66 mRNA in gastric cancer tissues, which may be one of the factors impacting on the function of tamoxifen treatment in gastric cancer patients.

The human ER 36 is known to mediate membraneinitiated estrogen and antiestrogen signaling, such as the mitogen-activated protein kinase (MAPK) signaling pathway, which may provide an explanation for the antiestrogen resistance observed in breast cancer patients. Similar results may present in gastric cancer patients. Furthermore, elucidation of the roles of the estrogen receptor and its variant in gastric cancer may contribute to diagnosis and treatment.

\section{References}

1. Freedman ND, Ahn J, Hou L, et al: Polymorphisms in estrogenand androgen-metabolizing genes and the risk of gastric cancer. Carcinogenesis 30: 71-77, 2009.

2. Xu CY, Guo JL, Jiang ZN, et al: Prognostic role of estrogen receptor alpha and estrogen receptor beta in gastric cancer. Ann Surg Oncol 17: 2503-2509, 2010.
3. Wang Z, Zhang X, Shen P, et al: Identification, cloning, and expression of human estrogen receptor-alpha36, a novel variant of human estrogen receptor-alpha66. Biochem Biophys Res Commun 336: 1023-1027, 2005.

4. Shi L, Dong B, Li Z, et al: Expression of ER-\{alpha\}36, a novel variant of estrogen receptor $\{$ alpha\}, and resistance to tamoxifen treatment in breast cancer. J Clin Oncol 20: 3423-3429, 2009.

5. Lee LM, Cao J, Deng H, et al: ER-alpha36, a novel variant of ER-alpha, is expressed in ER-positive and -negative human breast carcinomas. Anticancer Res 28: 479-483, 2008.

6. Jiang H, Teng R, Wang Q, et al: Transcriptional analysis of estrogen receptor alpha variant mRNAs in colorectal cancers and their matched normal colorectal tissues. J Steroid Biochem Mol Biol 112: 20-24, 2008.

7. Lin SL, Yan LY, Liang XW, et al: A novel variant of ER-alpha, ER-alpha36 mediates testosterone-stimulated ERK and Akt activation in endometrial cancer Hec1A cells. Reprod Biol Endocrinol 24: 102, 2009.

8. Wang Z, Zhang X, Shen P, et al: A variant of estrogen receptor-\{alpha\}, hER-\{alpha\}36: transduction of estrogen- and antiestrogen-dependent membrane-initiated mitogenic signaling. Proc Natl Acad Sci USA 103: 9063-9068, 2006.

9. Sobin LH, Wittekind C: UICC: TNM Classification of Malignant Tumours, ed 5. London, Wiley, 1997.

10. Schmittgen TD and Livak KJ: Analyzing real-time PCR data by the comparative C(T) method. Nat Protoc 3: 1101-1108, 2008.

11. Livak KJ and Schmittgen TD: Analysis of relative gene expression data using real-time quantitative PCR and the 2(-Delta Delta C(T). Method Methods 25: 402-408, 2001.

12. Jiang HP, Teng RY, Wang Q, et al: Estrogen receptor alpha variant ERalpha46 mediates growth inhibition and apoptosis of human HT-29 colon adenocarcinoma cells in the presence of 17beta-oestradiol. Chin Med J (Engl) 121: 1025-1031, 2008.

13. Chandanos E, Rubio CA, Lindblad M, et al: Endogenous estrogen exposure in relation to distribution of histological type and estrogen receptors in gastric adenocarcinoma. Gastric Cancer 11: 168-174, 2008.

14. Kameda C, Nakamura M, Tanaka H, et al: Oestrogen receptoralpha contributes to the regulation of the hedgehog signalling pathway in ERalpha-positive gastric cancer. Br J Cancer 16: 738-747, 2010.

15. Zhao XH, Gu SZ, Liu SX, et al: Expression of estrogen receptor and estrogen receptor messenger RNA in gastric carcinoma tissues. World J Gastroenterol 9: 665-669, 2003.

16. Wang M, Pan JY, Song GR, et al: Altered expression of estrogen receptor alpha and beta in advanced gastric adenocarcinoma: correlation with prothymosin alpha and clinicopathological parameters. Eur J Surg Oncol 33: 195-201, 2007.

17. Oshima CT, Wonraht DR, Catarino RM, Mattos D and Forones NM: Estrogen and progesterone receptors in gastric and colorectal cancer. Hepatogastroenterology 46: 3155-3158, 1999.

18. Raso MG, Behrens C, Herynk MH, et al: Immunohistochemical expression of estrogen and progesterone receptors identifies a subset of NSCLCs and correlates with EGFR mutation. Clin Cancer Res 15: 5359-5368, 2009.

19. Nüssler NC, Reinbacher K, Shanny N, et al: Sex-specific differences in the expression levels of estrogen receptor subtypes in colorectal cancer. Gend Med 5: 209-217, 2008.

20. Chandanos E, Lindblad M, Rubio CA, et al: Tamoxifen exposure in relation to gastric adenocarcinoma development. Eur J Cancer 44: 1007-1014, 2008.

21. Izawa M, Inoue M, Osaki M, et al: Cytochrome $\mathrm{P} 450$ aromatase gene (CYP19) expression in gastric cancer. Gastric Cancer 11: 103-110, 2008.

22. Harrison JD, Morris DL, Ellis IO, Jones JA and Jackson I: The effect of tamoxifen and estrogen receptor status on survival in gastric carcinoma. Cancer 64: 1007-1010, 1989. 